\title{
PRODUCTION AND UTILIZATION OF ENERGY AND CLIMATE ADAPTATION: GLOBAL TASKS AND LOCAL ROUTES
}

\author{
ELENA MAGARIL ${ }^{1}$, ROMEN MAGARIL ${ }^{2}$, DEBORAH PANEPINTO ${ }^{3}$, GIUSEPPE GENON ${ }^{3}$, \\ MARCO RAVINA $^{3}$, LUBOV TRUSHKOVA ${ }^{2}$ \& MARIA CHIARA ZANETTI $^{3}$ \\ ${ }^{1}$ Ural Federal University, Russian Federation. \\ ${ }^{2}$ Tyumen Industrial University, Russian Federation. \\ ${ }^{3}$ Politecnico di Torino, DIATI, Italy.
}

\begin{abstract}
Nowadays, when the energy, industry and transport sectors are adapting to climate change and need to reduce their environmental impact, it is vital that the optimal solutions are found for individual countries and their different circumstances. Territories, which have a hydrocarbon deficit, should use non-conventional energy sources while the countries with substantial resources of hydrocarbons should be focused on the strategy of raising the energy efficiency, i.e. to reduce the specific consumption of fuel consumed. The paper discusses these scenarios and describes some innovative technologies for both cases. Energy production from biomass is encouraged in some European countries by the granting of generous economic subsidies so that renewable energy plants, such as anaerobic digestion plants that produce biogas for use in internal combustion engines, in particular, are receiving much funding. An alternative technology for biogas valorisation could be that of biomethane (so called green gas) production through biogas purification and upgrading processes to remove $\mathrm{CO}_{2}, \mathrm{H}_{2} \mathrm{~S}$ and water vapour. Different technologies have been proposed to remove $\mathrm{CO}_{2}$ from gas streams, such as physical absorption, absorption by chemical solvents, cryogenic and membrane separation and $\mathrm{CO}_{2}$ fixation by chemical or biological methods. Production of biomethane and its introduction into the natural gas grid or its use as a fuel for vehicles could increase the energy efficiency and reduce specific emissions (combined cycle gas turbines, district heating of CHP units, methane powered vehicles). A simple and low-cost method of improving energy efficiency and environmental safety of transport by introducing into hydrocarbon fuels micro doses of a universal multifunctional additive is proposed. The method will make a significant contribution towards solving the problems of adapting to global climate change and improving the environment. It is capable of reducing specific fuel consumption by up to $12 \%$ and the requirements for a gasoline octane number by 10 points. It significantly reduces emission levels of greenhouse gases and toxic substances and provides complex improvement of the properties of fuels and the condition of engines.

Keywords: biogas, biomethane, climatic adaptation, energy efficiency, environmental safety, hydrocarbon fuels, multifunctional additive.
\end{abstract}

\section{INTRODUCTION}

According to the assessment of the International Resource Panel [1] the annual global use of material reached 70.1 billion tonnes in 2010, up from 23.7 billion tonnes in 1970. Thereby, over the past four decades, global material use has tripled and this has led to an acceleration of the processes of climate change and air pollution.

This creates serious challenges concerning the sustainability of modern civilization. Priorities and national solutions in terms of climate protection and the reduction of the overall environmental risk should be individualized in accordance with local conditions and opportunities $[2,3]$. In particular, the situation with the generation of electricity and transport development in Europe, a hydrocarbon deficient region, is different from that of Russia, the world's largest producer of oil and gas. Table 1 shows the total proven Russian hydrocarbon reserves in comparison with the values of reserves in the world as a whole and those in Europe and Eurasia. 
Table 1: Total proved reserves of oil, natural gas, and coal*.

\begin{tabular}{llllllll}
\hline & \multicolumn{2}{c}{ Total World } & \multicolumn{3}{c}{ Europe and Eurasia } & \multicolumn{2}{c}{ Russia } \\
\cline { 2 - 8 } & $\begin{array}{l}\text { Billion } \\
\text { tonnes** }\end{array}$ & $\begin{array}{l}\text { Share of } \\
\text { total, \% }\end{array}$ & $\begin{array}{l}\text { Billion } \\
\text { tonnes }\end{array}$ & $\begin{array}{l}\text { Share of } \\
\text { total, } \%\end{array}$ & $\begin{array}{l}\text { Billion } \\
\text { tonnes }\end{array}$ & $\begin{array}{l}\text { Share of } \\
\text { total, \% }\end{array}$ & $\begin{array}{l}\text { Share of Europe } \\
\text { and Eurasia, \% }\end{array}$ \\
\hline Oil & 239.4 & 100.0 & 21.0 & 9.1 & 14.0 & 6.0 & 67.0 \\
Natural & 186.9 & 100.0 & 56.8 & 30.4 & 32.3 & 17.3 & 56.8 \\
Gas & & & & & & & 50.6 \\
Coal & 891,531 & 100.0 & 310,538 & 34.8 & 157,010 & 17.6 & 50.6 \\
\hline
\end{tabular}

*Based on the data from Ref. [4].

**The data for natural gas are indicated in trillion cubic metres.

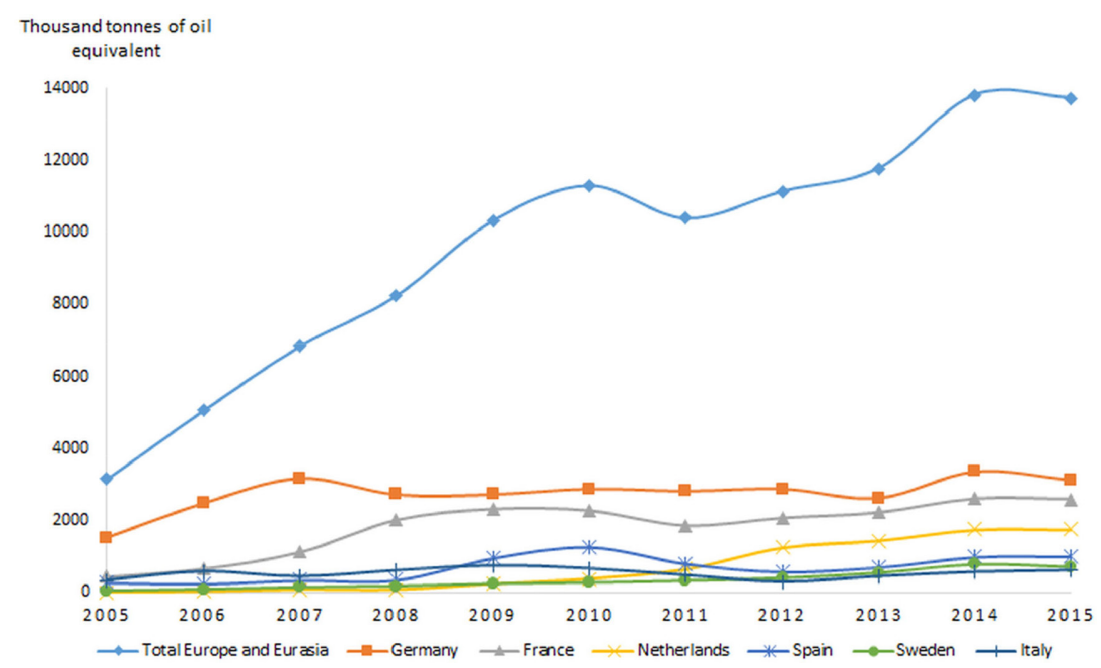

Figure 1: Dynamics of biofuel consumption (based on the data from Ref. [4]).

Therefore, the task of selecting the optimal technologies must take into account the local conditions. For the countries with substantial hydrocarbons resources an important task is the overall increase in energy efficiency, which will contribute to the growth of competitiveness of the national economy. It is important for European countries to focus their efforts on progress in technology that will reduce the cost of alternative energy. Figure 1 shows the dynamics for the consumption of biofuels (except for fuel ethanol and biodiesel) for some European countries.

It is necessary to direct investment flows to projects that improve energy efficiency and develop new technologies in energy, industry and transport. In addition, there is a requirement for the immediate implementation of low-cost measures that take into account the local conditions. Such measures can have a significant impact in the short term.

\section{AN APPROACH TO BIOGAS VALORISATION}

In order to reduce and minimize the effect of greenhouse gas (GHG) emission the European Union with the Directive 2009/28/EC has promoted the use of renewable sources, for the 
energy production, instead the fossil fuel. In this context the use of biomasses is an interesting example of this application.

In the field of biomasses conversion to energy we can identify two different possibilities mostly connected to the molecular structure and to the water content of the biomasses $[5,6]$ :

- Thermochemical processes (in particular direct combustion, gasification and also pyrolysis): these processes are convenient for biomass with carbon to nitrogen ratio $(\mathrm{C} / \mathrm{N})$ higher than 30 and with a moisture content lower than $30 \%$. In this category we find all the vegetable biomasses;

- Biochemical processes (in particular anaerobic digestion): these processes are suitable for biomass with carbon to nitrogen ratio $(\mathrm{C} / \mathrm{N})$ lower than 30 and with moisture higher than $30 \%$. In this category we find the aquatic cultures, some agricultural by products, municipal and industrial effluents.

In this study the authors analyzed in particular the biochemical processes with the anaerobic digestion of different biomasses (agricultural products such as for example maize silage, sorghum and organic waste), which in fact is today the most widespread technology used in order to obtain bioenergy. According to research performed by the Fraunhofer Institute [7], there were about 10,000 biogas units in Europe in 2012 with the expected increase to 13,500 by 2016 .

The biogas produced from anaerobic digestion of different biomasses is in general valorized from the energetic point of view using internal combustion engines [8]. In this way the production of electric energy or combined electric and thermal energy is possible.

Biogas produced by anaerobic digestion is composed mainly by methane $(40 \%-65 \%)$ and carbon dioxide $(25 \%-60 \%)$. Trace amount of other components such as water $(2 \%-8 \%)$, hydrogen sulphide $(0.005 \%-1.5 \%)$, nitrogen $(<2 \%)$, ammonia $(<1 \%)$ and carbon monoxide $(<0.6 \%)$ can be present. In account of the great amount of methane present an alternative use of biogas is the production of biomethane $[9,10]$. Biomethane, if adequately compressed, could be used as fuel for vehicles or injected into natural gas pipeline. In order to obtain the biomethane the biogas treatment processes are divided into:

- biogas cleaning to remove trace components harmful to the natural gas grid through chemical physical and biological processes;

- biogas upgrading, where $\mathrm{CO}_{2}$ is removed to meet the purity and calorific value required for natural gas use.

- Biogas upgrading techniques could be [9-11]:

- physical absorption with pressurized water;

- physical absorption with pressurized organic solvent;

- chemical absorption with aqueous alkanolamine solutions (MEA/DEA etc.);

- pressure and Vacuum Swing Adsorption (PSA/VSA);

- membrane separation;

- cryogenic separation.

The most applied techniques in Europe are absorption with pressurized water and PSA. 


\subsection{Biogas plant}

In the present study some results reported in a previous work [12] are reported and analyzing. In particular the study analyzes an anaerobic digestion plant (mesophilic condition) fed with cattle slurry and maize silage.

From the energetic point of view the available thermal energy of the produced biogas is 2.5 MW [13]. Table 2 and Figure 2 show the specifics of the studied biogas plant.

2.2 Environmental evaluation and comparison between the production and use of biogas and the production of biomethane

In this section the results of the implementation of the dispersion model for the two alternative solutions: anaerobic digestion plant and valorization of the biogas with combustion (Fig. 2) and production of biomethane (Fig. 3) are reported and analyzed. The pollutants analyzed are $\mathrm{NO}_{\mathrm{x}}$ and $\mathrm{PM}$ (particulate matter) (that are the two main contaminants responsible to the local impact) [12].

In order to evaluate the pollutant dispersion a Gaussian model was used. The meteorological data was supplied by the Piedmont Regional Agency for the Environmental Protection (ARPA).

Table 2: Specific features of the analyzed plant.

\begin{tabular}{|c|c|c|c|c|c|c|c|}
\hline Substrates & $\begin{array}{l}\text { Input } \\
(t / d)\end{array}$ & $\begin{array}{l}\text { Dry matter } \\
\text { mass } \\
\text { fraction }\end{array}$ & $\begin{array}{l}\text { Volatile } \\
\text { solids/ dry } \\
\text { matter mass } \\
\text { fraction }\end{array}$ & $\begin{array}{l}\text { Volatile } \\
\text { solids } \\
\text { (VS) } \\
\text { (t VS/d) }\end{array}$ & $\begin{array}{l}\text { Biogas yield/ } \\
\text { volatile } \\
\text { solids } \\
\left(\mathrm{m}^{3} / \mathrm{t} \mathrm{VS}\right)\end{array}$ & $\begin{array}{l}\text { Biogas } \\
\text { production } \\
\left(\mathrm{m}^{3} / \mathrm{d}\right)\end{array}$ & $\begin{array}{l}\text { Biogas } \\
\text { production } \\
(\mathrm{t} / \mathrm{d})\end{array}$ \\
\hline $\begin{array}{l}\text { Cattle } \\
\text { manure }\end{array}$ & 48.5 & 0.22 & 0.75 & 8.0 & 400 & 3200.3 & 3.52 \\
\hline $\begin{array}{l}\text { Maize } \\
\text { silage }\end{array}$ & 47.5 & 0.35 & 0.95 & 15.5 & 700 & 10850.5 & 11.94 \\
\hline Total & 96 & 0.56 & - & 23.5 & - & 14050.9 & 15.46 \\
\hline
\end{tabular}

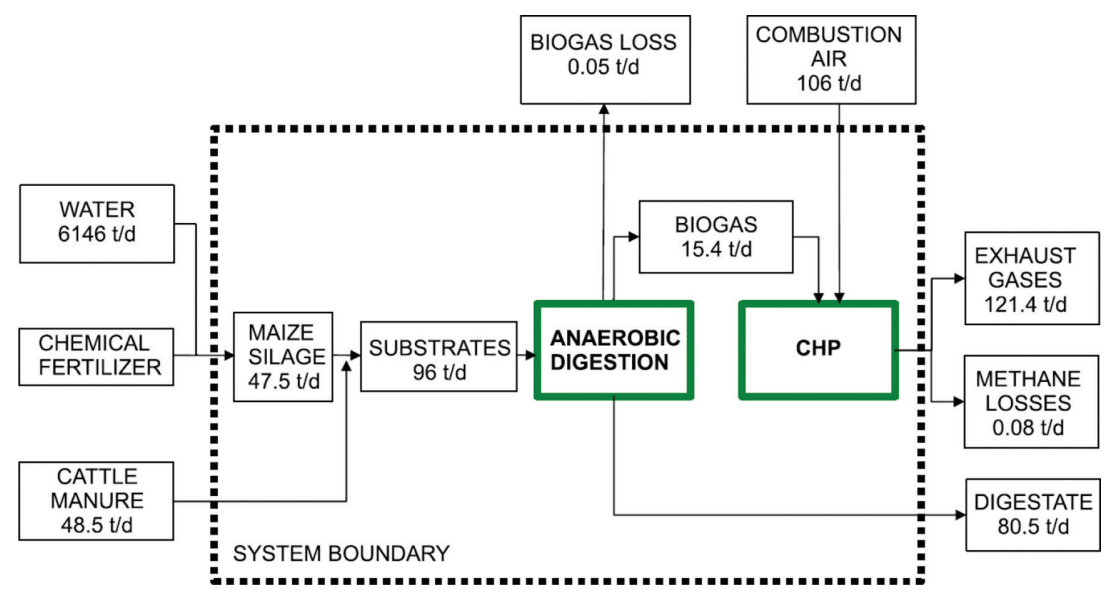

Figure 2: Scheme of the analysed process. 
In order to define the turbulence the six 'stability classes' defined from Pasquill are used: A, B, C, D, E, and F [14]; in particular class A means the most unstable or most turbulent conditions, instead class F means the most stable or least turbulent conditions.

In the simulations the two stability classes A (unstable condition) and F (stable condition) are used. The results for the two scenarios are reported on the iso-concentration maps of Figures 4 and 5 for $\mathrm{NO}_{\mathrm{x}}$ and Figures 6 and 7 for PM.

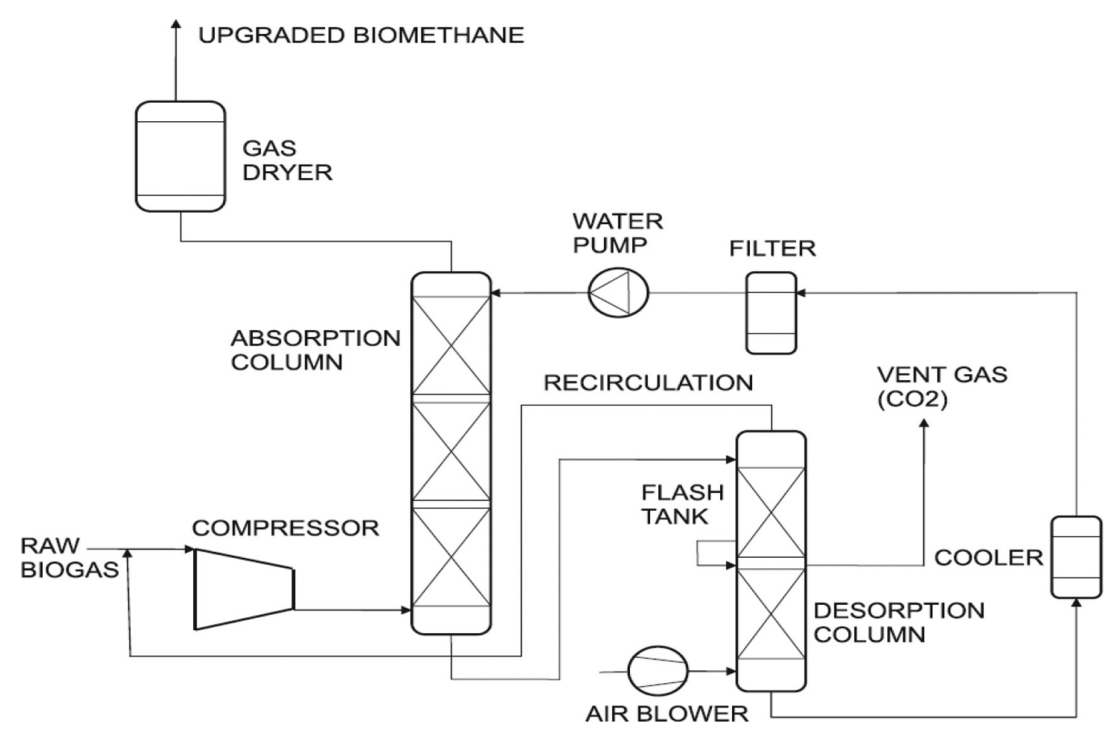

Figure 3: Scheme of the biogas upgrading process.
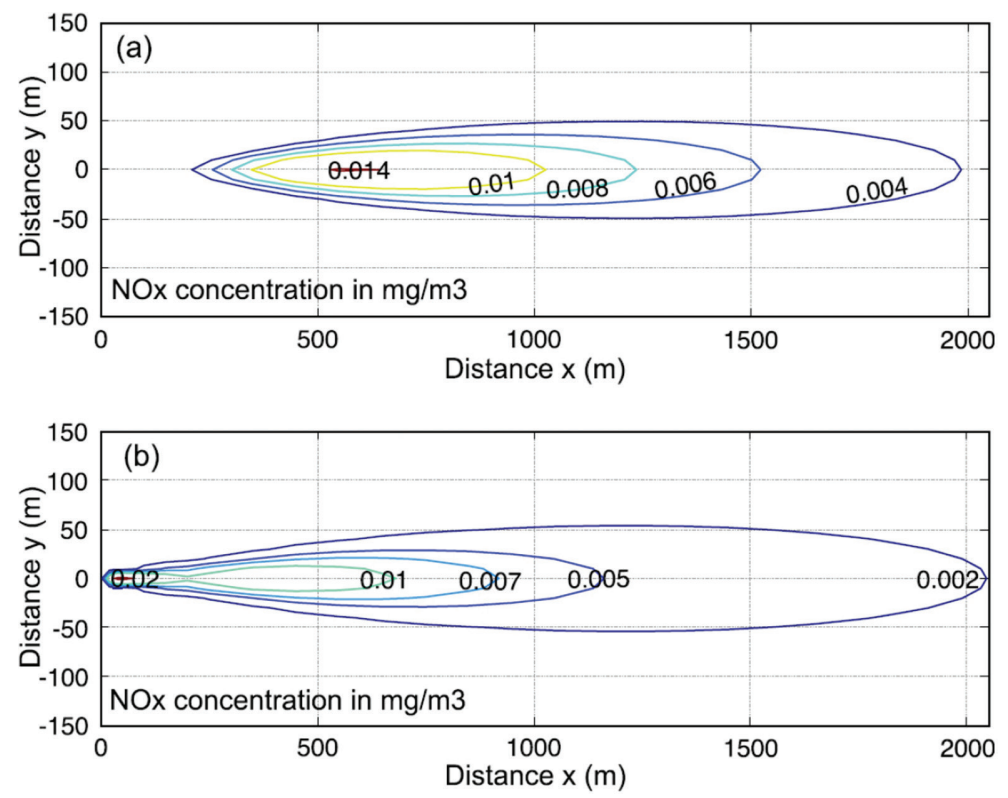

Figure 4: $\mathrm{NO}_{\mathrm{x}}$ dispersion for biogas plant (a) and methane boiler (b) - stability class: $\mathrm{F}$. 

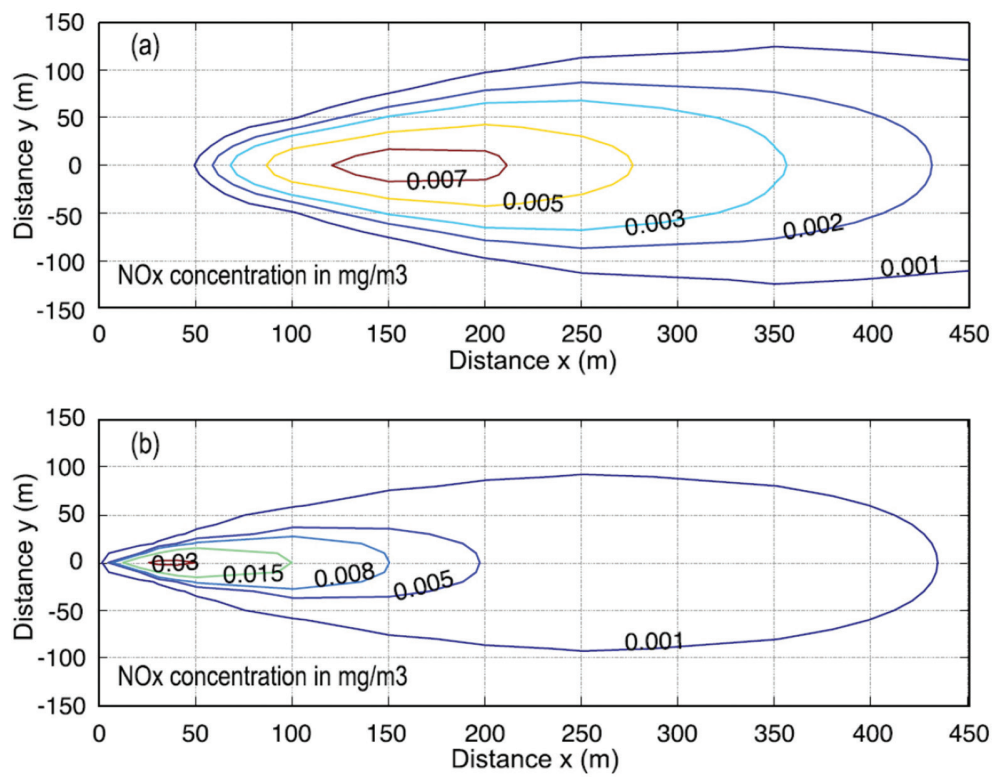

Figure 5: $\mathrm{NO}_{\mathrm{x}}$ dispersion for biogas plant (a) and methane boiler (b) - stability class: A.
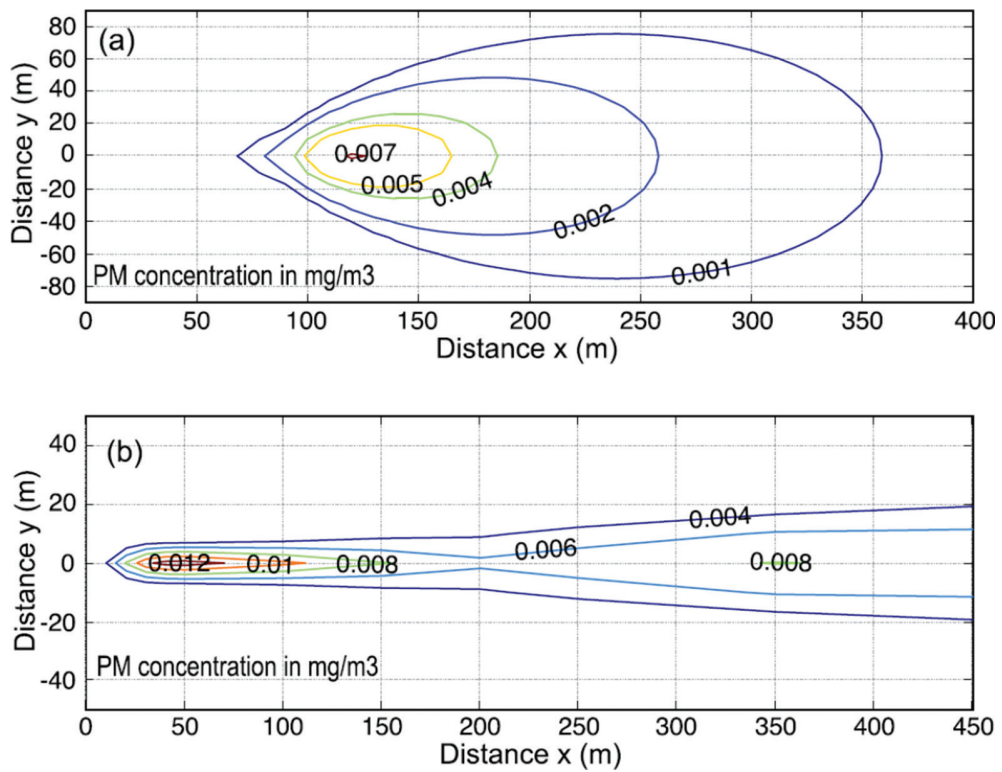

Figure 6: PM dispersion for biogas plant (a) and methane boiler (b) - stability class: F.

Italian regulations impose an annual concentration limit for $\mathrm{NO}_{\mathrm{x}}$ of $40 \mu \mathrm{m} / \mathrm{m}^{3}$, for $\mathrm{PM}_{10}$ of $40 \mu \mathrm{m} / \mathrm{m}^{3}$ and for $\mathrm{PM}_{2.5}$ of $25 \mu \mathrm{m} / \mathrm{m}^{3}$.

The emissions derived from the two scenarios analyzed are lower than the maximum value indicated from the Italian regulation; anyway, the additional contribution to the normal presence of pollutants may be significant. In fact the background situation concerning these 

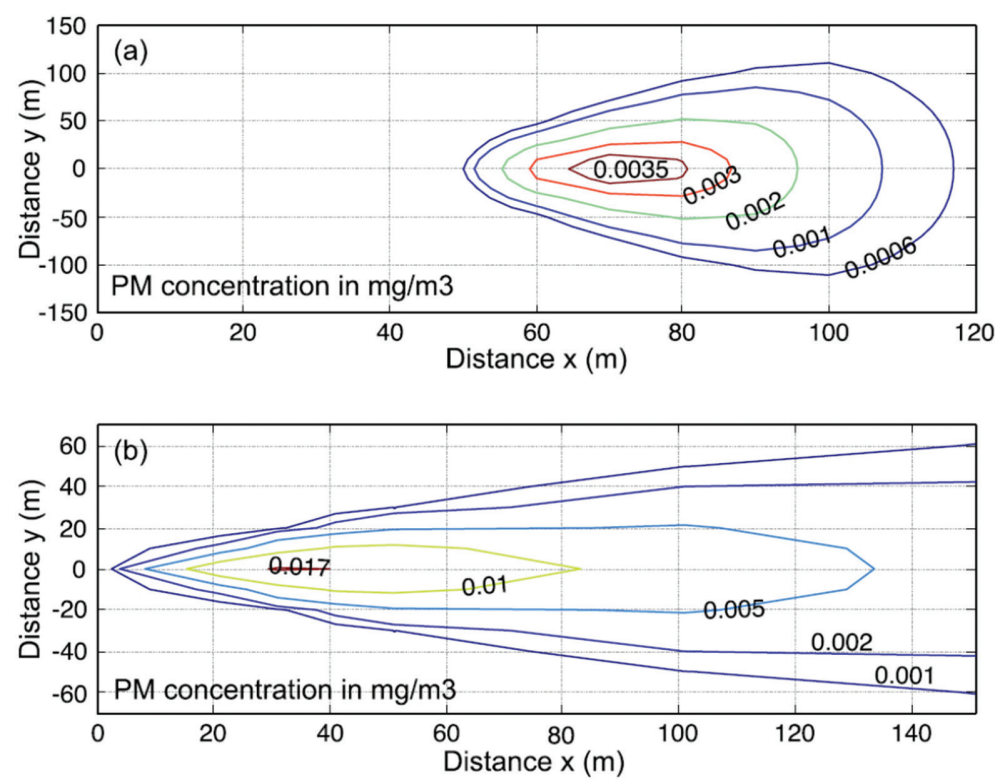

Figure 7: PM dispersion for biogas plant (a) and methane boiler (b) - stability class: A.

contaminants (in particular for the $\mathrm{NO}_{\mathrm{x}}$ ) is already critical and so the higher $\mathrm{NO}_{\mathrm{x}}$ and $\mathrm{PM}$ concentrations may cause negative effects for the possible recipients (human or vegetable).

\section{CLIMATIC ADAPTATION AND SUSTAINABILITY OF TRANSPORT CONSUMING TRADITIONAL MOTOR FUELS}

3.1 Problems of improving the energy efficiency and environmental safety of transport operation

Modern problems of transport sustainability represent the critical comprehensive environmental and economic challenge to civilization. This is due to the rapid growth of a world vehicle fleet adapted to liquid petroleum fuel whose consumption is also continually increasing while oil and gas resources are rapidly depleting. Vehicles are one of the major consumers of oil products and consequently, the generators of greenhouse gases and toxic byproducts of combustion into the atmosphere, as illustrated in Figure 8. This exacerbates both the problem of global climate change and the environmental situation. Traditional fuels and the products of combustion bring increased risk to the environment the solution to which requires a systematic approach [15]. Adapting transport to climate change requires a reduction in specific fuel consumption. Energy efficiency and environmental safety of vehicles' operation are highly dependent on the quality of the fuel used [16-21]. An improvement in the design of vehicles and engines, as well as other methods for reducing the negative effects of transport operation for the environment are inefficient when using poor quality fuel. In this way, the improvement of the quality of motor fuels should be considered as a priority task.

The importance of improving the energy efficiency and environmental safety of vehicles require the rapid implementation of innovative and highly efficient technological solutions. Despite efforts to develop and deploy the alternative fuels and energy for transport, they have 

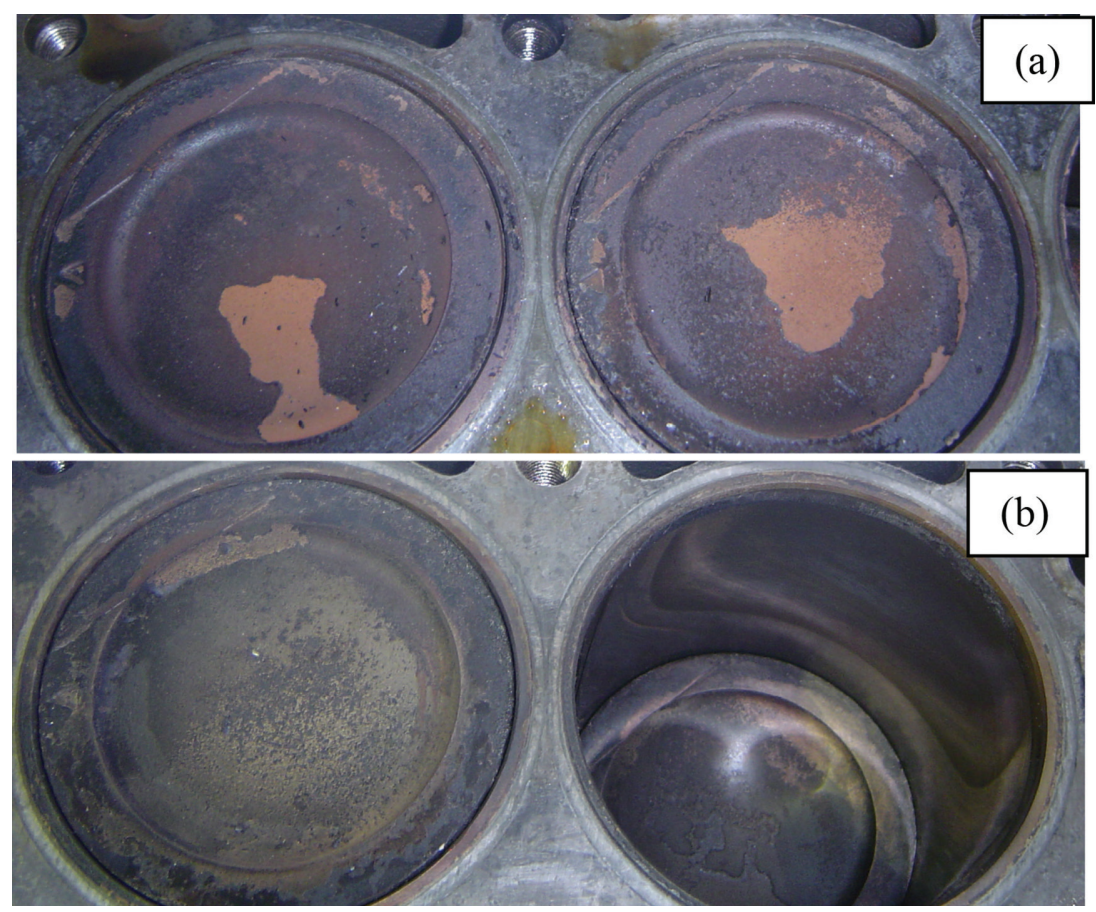

Figure 9: The cylinder faces of internal combustion engines after the test run: (a) control car (without the additive); (b) testing car after application of the additive.

ensures the engine fuel system is kept clean, lubricating properties, reduced loss of gasoline through evaporation and improved mixture formation when injecting the fuel into the engine. Table 2 demonstrates the results of the developed multifunctional additive application (the laboratory, test bench, traffic operation and experimental-industrial checkout). Compulsory application of the additive will reduce dependence on a gasoline octane rating [28, 29]. Consumption of gasoline and diesel fuels by engines will also be reduced. Unique in its simplicity, efficiency and low cost, the method integrates the characteristics and capabilities of the nanotechnology and effects equivalent to the use of package of the effective additives to the fuel. Use of the multifunctional additive significantly reduces the emission of greenhouse gases and toxic substances during the operation of vehicles and improves the condition of the engines. The emission of benzo( $\alpha)$ pyrene, which is the strongest carcinogen, is reduced by $95 \%$. Using fuel that contains the additive produces no additional toxic substances in the exhaust gases that were not observed without the additive.

The high efficiency of the developed additive was confirmed by its application in the production of approximately 360,000 tons of gasoline and 40,000 tons of diesel fuel, which were used in the experimental-industrial checkout. The additive is synthesized from obtainable, low-cost substances. Its production does not require highly qualified engineers and complicated facilities. The additive can be introduced into the during the production of the fuel, into the finished product, at the petrol station and directly into the vehicle's fuel tanks. 
Table 3: Effects of the additive application (concentration of the additive $9.25 \mathrm{ppm}$ in gasoline and $27.75 \mathrm{ppm}$ in diesel fuel)*.

\begin{tabular}{lll}
\hline Characteristics & $\begin{array}{l}\text { Gasoline engines, } \\
\text { gasoline }\end{array}$ & $\begin{array}{l}\text { Diesel engines, } \\
\text { diesel fuel }\end{array}$ \\
\hline Fuel consumption & $-5 \%-12 \%$ & $-4 \%-7 \%$ \\
Reduction of carbon deposits & $\sim-95 \%-100 \%$ & $\sim-95 \%-100 \%$ \\
$\begin{array}{l}\text { Detergent properties, decrease of cleaning time, } \\
\text { times }\end{array}$ & 2.33 & 2.33 \\
Emissions: & & \\
Carbon monoxide & $-15 \%-30 \%$ & $-15 \%-17 \%$ \\
Nitrogen oxides & $-20 \%-26 \%$ & $-20 \%-22 \%$ \\
$\mathrm{C}_{\mathrm{m}} \mathrm{H}_{\mathrm{n}}$ & $-8 \%-35 \%$ & $-35 \%-37 \%$ \\
benzo(a)pyrene and its homologues & $-95 \%-96 \%$ & - \\
soot & - & $-40 \%-50 \%$ \\
Requirements to octane number & $-7-12$ items & - \\
Cetane number & - & +3 items \\
Lubricating properties (coefficient of static friction) & - & $-25 \%$ \\
Saturated vapor pressure & $-15 \%-25 \%$ & - \\
Vaporization loss of gasoline & $-17 \%-30 \%$ & - \\
\hline
\end{tabular}

$*$ Cost of the additive $1 \$ /$ ton of gasoline, $3 \$ /$ ton of diesel fuel.

\section{CONCLUSIONS}

The problems of the energy, industrial and transport sectors adapting to climate change and the need to mitigate their environmental hazards cannot be overemphasized in the context of modern civilization and its future development and efforts to achieve this must be integrated. However, the implementation of the global strategy and the selection of the optimal technological solutions depend on the specific conditions in different countries.

The priorities should be increasing the energy efficiency of the technological processes and transport operation and the development of competitive alternative fuels and energy.

The study evaluated the biogas production process while considering different end-use solutions with particular reference to limiting atmospheric pollution and also reducing GHG emissions (the main reason for climate change). In this specific case, the present study points out that upgrading biogas to biomethane may represent an environmentally friendly alternative to the on-site combustion of biogas in CHP units, especially in the cases where the energy content of the gas is not fully cogenerated and all or part of the thermal energy produced is not capitalized.

The proposed method for improving the energy efficiency and environmental safety of transport operation using the universal multifunctional additive creates not only environmental benefits but also high economic motivation for its use. The fuel producers are motivated due to lower requirements for the octane number of gasoline, which dramatically reduces the cost of gasoline production. The consumers will get improved fuel economy for their vehicles. Widespread implementation of the method will significantly mitigate the negative environmental impact of transport operation and contribute to the process of adapting transport to climate change. 


\section{ACKNOWLEDGEMENT}

This research was supported by Act 211 Government of the Russian Federation, contract № 02.A03.21.0006.

\section{REFERENCES}

[1] Global Material Flows and Resource Productivity: Assessment Report for the UNEP International Resource Panel, 2016.

[2] Genon, G., Panepinto, D. \& Viggiano, F., Sustainability in energy production. International Journal of Energy Production and Management, 1(1), pp. 16-32, 2016. https://doi.org/10.2495/EQ-V1-N1-16-32

[3] Ragazzi, M., Ionescu, G. \& Cioranu, S.I., Assessment of environmental impact from renewable and non-renewable energy sources. International Journal of Energy Production and Management, 2(1), pp. 8-16, 2017. https://doi.org/10.2495/EQ-V2-N1-8-16

[4] BP Statistical Review of World Energy, 2016.

[5] Cherubini, F., GHG balances of bioenergy systems - overview of key steps in the production chain and methodological concerns. Renewable Energy, 35(7), pp. 1565-1573, 2010. https://doi.org/10.1016/j.renene.2009.11.035

[6] Blengini, G.A., Brizio, E., Cibrario, M. \& Genon, G., LCA of bioenergy chains in Piedmont (Italy): a case study to support public decision makers towards sustainability. Resources, Conservation and Recycling, 57, pp. 36-47, 2011.

https://doi.org/10.1016/j.resconrec.2011.10.003

[7] Fraunhofer Insitute, Biogas to Energy. Cologne/Oberhausen. Report, 2012.

[8] Patterson, T., Esteves, S., Dinsdale, R. \& Guwy, A., Life cycle assessment of biogas infrastructure options on a regional scale. Bioresource Technology, 102(15), pp. 7313-7323, 2011. https://doi.org/10.1016/j.biortech.2011.04.063

[9] Bakonyi, P., Nemestothy, N., Simon, V. \& Belafi-Bako, K., Review on the start-up experiences of continuous fermentative hydrogen producing bioreactors. Renewable and Sustainable Energy Reviews, 40, pp. 806-813, 2014. https://doi.org/10.1016/j.rser.2014.08.014

[10] Panepinto, D., Brizio, E. \& Genon, G., Atmospheric pollutants and air quality effects: Limitation costs and environment advantages (a cost-benefit approach). Clean Technologies and Environmental Policy, 16(8), pp. 1805-1813, 2014.

https://doi.org/10.1007/s10098-014-0727-6

[11] Makaruk, A., Miltner, M. \& Harasek, M., Membrane biogas upgrading processes for the production of natural gas substitute. Separation and Purification Technology, 74(1), pp. 83-92, 2010. https://doi.org/10.1016/j.seppur.2010.05.010

[12] Ravina, M. \& Genon, G., Global and local emissions of a biogas plant considering the production of biomethane as an alternative end- use solution. Journal of Cleaner Production, 102, pp. 115-126, 2015. https://doi.org/10.1016/j.jclepro.2015.04.056

[13] Panepinto, D., Genon, G., Brizio, E. \& Russolillo, D., Production of green energy from co-digestion: perspectives for the province of Cuneo, energetic balance and environmental sustainability. Clean Technologies and Environmental Policy, 15(6), pp. 1055-1062, 2013. https://doi.org/10.1007/s10098-012-0568-0

[14] Ratnesh, T., Chakraborty, M.K. \& Tewary, B.K., Generation and dispersion of total suspended particulate matter due to mining activities in an indian opencast coal project, monitoring, control and effects of air pollution, Prof. Andrzej G. Chmielewski (Ed.), ISBN: 978-953-307-526-6, InTech, available at http://www.intechopen.com/books/ monitoring-control-and-effects-of-air-pollution/generation-and-dispersion-oftotal-suspended-particulate-matter-due-to-mining-activities-in-an-india 
[15] Magaril, E.R., Abrzhina, L.L. \& Belyaeva, M.A., Environmental damage from the combustion of fuels: Challenges and methods of economic assessment. WIT Transactions on Ecology and the Environment, 190(2), WIT Press: Southampton and Boston, pp. 1105-1115, 2014.

[16] Boulter, P.G. \& Latham, S., Emissions factors 2009: Report 5 - a review of the effects of fuel properties on road vehicle emissions. TRL Report PPR358, TRL Limited, Wokingham, 2009.

[17] Karonis, D., Lois, E., Stournas, S. \& Zannikos, F., Correlations of exhaust emissions from a diesel engine with diesel fuel properties. Energy and Fuels, 12(2), pp. 230-238, 1998. https://doi.org/10.1021/ef9700588

[18] Magaril, E., The solution to strategic problems in the oil refining industry as a factor for the sustainable development of automobile transport. WIT Transactions on Ecology and the Environment, 190(2), pp. 821-832, 2014. https://doi.org/10.2495/eq140762

[19] Magaril, E., Increasing the efficiency and environmental safety of vehicle operation through improvement of fuel quality. International Journal of Sustainable Development and Planning, 10(6), pp. 880-893, 2015. https://doi.org/10.2495/SDP-V10-N6-880-893

[20] Magaril, E. \& Magaril, R., Fuel quality: challenges to the sustainable development of automobile transport and approach to solution. E3S Web of Conferences, 6, p. 03001, 2016.

[21] Zannis, T.C., Hountalas, D.T., Papagiannakis, R.G. \& Levendis, Y.A., Effect of fuel chemical structure and properties on diesel engine performance and pollutant emissions: review of the results of four European research programs. SAE International Journal of Fuels and Lubricants, 1(1), pp. 384-419, 2009. https://doi.org/10.4271/2008-01-0838

[22] Bennett., J., Advanced fuel additives for modern internal combustion engines. Alternative Fuels and Advanced Vehicle Technologies for Improved Environmental Performance. Towards Zero Carbon Transportation, ed. R. Folkson, Woodhead Publishing Ltd: UK, pp 165-194, 2014. https://doi.org/10.1533/9780857097422.1.165

[23] Magaril, E., Improving the efficiency and environmental safety of gasoline engine operation. WIT Transactions on the Built Environment, 130, pp. 437-485, 2013. https://doi.org/10.2495/UT130341

[24] Magaril, E. \& Magaril, R., Improving the environmental and performance characteristics of vehicles by introducing the surfactant additive into gasoline. Environmental Science and Pollution Research, 23(17), pp. 17049-17057, 2016. https://doi.org/10.1007/s11356-016-6900-1

[25] Srivastava, S.P. \& Hancsók, J., Fuels and Fuel-Additives, John Wiley \& Sons Inc: Hoboken, New Jersey, 2014. https://doi.org/10.1002/9781118796214

[26] Magaril, E., Improving car environmental and operational characteristics using a multifunctional fuel additive. WIT Transactions on Ecology and the Environment, 147, pp. 373-384, 2011. https://doi.org/10.2495/air110351

[27] IEA $\mathrm{CO}_{2}$ Emissions from Fuel Combustion, OECD/IEA, Paris, 2016.

[28] Magaril, E., The influence of carbonization elimination on the environmental safety and efficiency of vehicle operation. International Journal of Sustainable Development and Planning, 8(2), pp. 231-245, 2013. https://doi.org/10.2495/SDP-V8-N2-231-245

[29] Magaril, E., Carbon-free gasoline engine operation. International Journal of Sustainable Development and Planning, 10(1), pp. 100-108, 2015. https://doi.org/10.2495/SDP-V10-N1-100-108 